Kozubíková, L., Dvorský, J., Cepel, M. \& Balcerzak, A. P. (2017). Important characteristics of an entrepreneur in relation to risk taking: Czech Republic case study. Journal of International Studies, 10(3), 220-233. doi:10.14254/2071-

$8330.2017 / 10-3 / 16$

\title{
Important characteristics of an entrepreneur in relation to risk taking: Czech Republic case study
}

\section{Ludmila Kozubíková}

Tomas Bata University in Zlin, Crech Republic

Email:kozubikova@fame.utb.cz.

\section{Ján Dvorský}

Tomas Bata University in Zlin

Crech Republic

Email:j1dvorsky@fame.utb.cz.

\section{Martin Cepel}

LIGS University LLC, Honolulu, Hawaii,

USA

Email: cepel@benzinol.com

\author{
Adam P. Balcerzak \\ Nicolaus Copernicus University, \\ Torun, Poland, \\ Email:adam.balcerzak@umk.pl
}

Abstract. New businesses arising at the market usually operate in the sector of small and medium-sized enterprises and account for a significant part of the whole global economy. Not only the success of a start-up company, but also its sequel within the SME sector are significantly influenced by entrepreneur's personality. The aim of this article is to explore the attitude to financial risk in relation to sociodemographic characteristics (gender, education, age) and the most important personality traits of entrepreneurs (risk-taking, decisiveness, optimism). We have analyzed the data collected from 1141 respondents during 2015 in 14 regions of Czech Republic. Empirical results of our paper show that the researched entrepreneurs rather can't manage financial risks in their firms regardless their gender, education, age or personality traits. Most entrepreneurs consider the importance of financial risk to increase during the crisis period. These opinions differed in relation to age, gender and such personality traits as "decisiveness" and "optimism". The results also show that the entrepreneurs try to minimise the financial risk through building-up reserves in relation to such qualities as "risk-taking" and "decisiveness" in comparison to a rather negative attitude to "optimism".
Received:

June, 2017

1st Revision:

August, 2017

Accepted: September, 2017

DOI:

$10.14254 / 2071$ $8330.2017 / 10-3 / 16$ 
Keywords: entrepreneur's personality, personality traits, risk-taking, motives for entrepreneurship, Czech Republic.

JEL Classification: L26

\section{INTRODUCTION}

Due to their important role in establishing and maintaining well-functioning market economy, SMEs are considered to be important generators of economic development. Because of their special nature arising from their size, capital endowment, specifics of management, the entrepreneur's personality plays a vital role. Because of the important role of the entrepreneur in managing SMEs and the importance of SMEs for future economic performance the issue of "ideal" personality traits of entrepreneur is a frequently discussed topic in both theory and practice. Also, the question of gender in leading and risk-taking by SMEs is considered to be important.

Financial risks are related to the development of financial markets and the use of various financial instruments. They have a complex character and can be classified into the following groups: funding risk, credit risk, liquidity risk, the risk of changes in interest rates, foreign exchange risk, inflation risk and counterparty risk. This definition of financial risk is generally accepted in academic areas. The authors of this paper agree with this definition, though it can be also refined as in Fetisovová et al. (2012), for example.

With respect to the current social situation, its norms and rules of operation, only those who possess the following personality traits have a chance to reach a significant success: higher level of self-confidence, self-assurance, self-believe, mental strain resistance, the ability to foresee, independent thinking, willingness to take risks, flexibility, social intelligence and communication skills. Many reached their goals also due to their negative traits which can come along with the ones mentioned above. We can mention harshness, thoughtlessness, dishonesty. It all goes back to the way of thinking. The unsuccessful ones talk about restrains and find excuses, yet those who are successful search for solutions. The successful ones know what they want and fully realise that they can reach it through hard and smart work. It is not enough to think, it is necessary to take action. It is better to make hundred mistakes and succeed only once than stagnate the whole life thinking how to be successful (Vesecký, 2014).

In our article we study the attitude to financial risk in relation to sociodemographic characteristics (gender, education, age) and the most important personality traits of entrepreneurs (risk taker, decisiveness, optimism).

This article has the following structure. The theoretical part introduces different views on the most important personality traits of entrepreneurs and different attitudes of males and females to financial risks. The next section presents the objectives, methodology and information resources, which were used in this research. The final section overviews the most important recommendations for the theoretical field and actual business practice.

\section{LITERATURE REVIEW}

Entrepreneurship has many aspects. For the settlement of a company in a long time period it is necessary to successfully survive and meet the expectations and objectives of the owners. The situation is not different in SMEs, which face a number of obstacles due to their nature.

The personality of entrepreneurs plays an important role in the management of SMEs. Because they are supposed to be leaders, their personality traits affect the direction of the company's future development. 
A decision to become an entrepreneur comes along with a certain approach to life and the world around. A person who wishes to become an entrepreneur must meet certain prerequisites. For a person who wants to gain ground successfully with an entrepreneurial intention, it is important "to be enterprising", i.e. to have certain dispositions and personal traits. Dispositions include abilities, knowledge and skills in a sense of performance potential of the entrepreneur. Personal traits characterise the personality of the entrepreneur and include non-specific general attributes, such as clear record, trustworthiness, honesty, fairness, adherence to principles, consistency, politeness, consideration, precision, and also some specific ones such as decisiveness, dutifulness, a spirit of initiative, goal orientation, persistence, self-reliance, responsibility, diligence, and social skills. (Veber et al., 2005)

According to Frese and Gielnik (2014) entrepreneurs should be capable of having the features of several personalities at once and as one person to demonstrate the ability to act as investors, inventors, accountants, dispute investigators, leaders, technologists, marketing specialists and top sellers. Because of this, the more knowledge and skills the entrepreneur is capable of demonstrating the better. The same authors discuss the question of optimism that is required for entrepreneurs to believe in the feasibility and success of an idea but may have negative consequences because it can lead to overextension and flawed forecasts.

Hines (2004) believes there are at least 9 other characteristics (apart from the fact that successful entrepreneurs should be honest, intelligent, skilful and well-educated in their chosen fields) that he values highly: energy level, ego, courage, enthusiasm, desire to make money, creativity, resourcefulness, tenacity, and leadership qualities.

The results of research of Ugalde-Binda et al. (2014) show that the success factors most frequently mentioned by respondents were commitment to quality and hard work, followed by the ability to adapt to change, business experience and motivation. They also mentioned perseverance.

The findings of Beugelsdijk and Noorderhaven (2005) show that entrepreneurs are more individually oriented than the rest of the population. Individual responsibility and effort are distinguishing characteristics of the self-employed versus the general population.

Zhao and Seibert (2006) found evidence that entrepreneurs differ from managers in four fundamental areas of personality (neuroticism, agreeableness, openness to experience, conscientiousness).

According to Omerzel and Kušce (2013) and previous entrepreneurial research in addition to personality traits it is also important to consider the influence of the environment (social, cultural, political and economic contextual factors).

According to the results of Bruttel and Fischbacher (2013), persons as leaders are characterized by above-average cognitive skills and are predominantly male. They have strong preferences for efficiency, generosity, and against advantageous inequality, and do not primarily seek to maximize their personal monetary benefit or to obtain a positive public image. They have accurate beliefs about the extent to which others will follow their example. The authors found that leaders in the experiment had an internal locus of control and were more patient than non-leaders, but they didn't find an impact of the big five personality traits or risk attitude on leading-by-example. Finally, it was found that leaders as identified in the experiment were also more likely than non-leaders to engage in activities associated with taking the initiative in their real lives.

Hines (2004) states that to lead effectively, they must be able to recognize and encourage the best qualities, mental ones as well as economic, in their people. It is the ability of the entrepreneurs to stimulate, relate to, and empathize with their employees, officers, directors, and shareholders.

Veber et al. (2005) states that an entrepreneur should be a leader and should be a charismatic person. Charisma can be characterised as a personal charm, a set of personal characteristics well-received by others, 
based on that an entrepreneur can become a leader with an influence on the subordinates at work who are more open to accept his or her ideas, thoughts, opinions, stance. The same authors state that a typical personality trait of an entrepreneurial personality is proactivity, dynamism, optimism, creativity, initiative, positive thinking, etc.

Based on the opinions of different contributors in magazine Forbes (Rampton, 2014, Hall, 2012, Pofeldt, 2014) the following traits are considered to be the most important ones in an entrepreneur: passion, resilience, strong sense of self, flexibility, vision, courage/willingness to take risks, positive attitude, strength of character, integrity, ability to engender trust, dedication, creative, leadership skills, tenacity, independency, risk-taking.

Starting one's own business requires a reason, a motivation which is based on one's intrinsic stimuli.

Based on the research of entrepreneurial environment of SMEs in the Czech Republic (project IGA/FaME/2015/022, GA/2016/2), the most frequent reason to start business was a financial reason (money) $-29 \%$; next was a wish to have a job, than seeing entrepreneurship as a role, and finally, starting business out of a necessity because there was no other alternative.

There is strong evidence (Kepler \& Shane, 2007) of different motivations between male and female entrepreneurs. In particular, male entrepreneurs were more likely to start businesses to make money and to believe that starting a business is more important than spending time with one's family. Male entrepreneurs were significantly more likely to see business owners as community leaders, suggesting that male entrepreneurs are more highly motivated to start businesses to achieve recognition than women are. Finally, male entrepreneurs had significantly higher expectations for their new businesses than female entrepreneurs.

According to Smejkal and Raise (2006), risk is characterized in various ways: as the probability or possibility of loss or failure; as the variability of the possible results or the uncertainty of their achievement; as the variation between expected and real results; as the probability of any result different from the expected one; as the situation when the quantitative magnitude of a certain occurrence is subject to a certain probability distribution; as the danger of the negative variation from the target (so called net risk); as the possibility of loss or profit (so called speculative risk); as the uncertainty resulting from the asset value volatility (so called investment risk); as the average value of the loss function; as the possibility of a specific threat prospering from a specific system vulnerability.

Shuying and Mei (2014) argue that financial risk is one of the major reasons for SMEs default. Poor capital structure of the SMEs is another major reason for financial risk. The SMEs overwhelmingly depend on debt financing and as a result their debt ratio is higher in the capital. Therefore banks also charge higher interest rates and due to large debt burden the SMEs go to default. Authors propose that effective management of capital structure can reduce the debt burden and the financial risk of the SMEs.

The research of Feakins (2004) shows that banks are focusing more on the medium-sized companies rather than the small companies due to higher risk estimation. The study finds some major constraints in financing the SMEs from the commercial banks, e.g.: information gap, lack of collateral, etc. It is easier for banks to lend the money if the customer has any linkage with any corporate borrowers so that banks can gather some valuable information about the SME borrowers from the corporate clients.

The importance of the size of a company was confirmed also by Kundin and Erecgovac (2011). They proved that as the size of the firm increases, the interest rate decreases due to positive information about the firm in the market. However, they did not find any significant relationship between collateral and internal rating model in relation to access to credit to SMEs. During the period of financial distress, the credit spreads between large firms and small firms are intensified.

The study of Kim and Vonorts (2014) in ten European countries (Croatia, Czech Republic, Denmark, France, Germany, Greece, Italy, Portugal, Sweden and the UK) found that when young companies were 
faced with technology risk, financial risk and operational risk, they had engaged in a high networking activities by which they sought help from others. Moreover, the results show that technology risk and financial risk is highly associated with networking. Two thirds of the respondents replied that market risk was the major risk for their enterprise survival, i. e. high competition, poor demand of the product, advancement of new designs and narrow marketplace for selling their products, etc.

Moderate levels of risk-taking produce greater levels of international scope than do either low or high levels. Finding of Dai et al. (2014) concerning risk-taking point to the benefits of a moderate stance, as high levels of risk-taking raise the stakes of international activities while low levels discourage venturing abroad altogether.

There are a number of differences between male and female entrepreneurs (Radet al. 2014; Belluchi et al. 2010). What we know so far is that the differences in risk propensity and self-efficacy play a role in gender differences in entrepreneurial career choice. The data from the main study of Obschonka et al. (2014) suggest that not only the more "visible" gender differences such as those in human and social capital or situational obstacles preventing women from pursuing entrepreneurship (e.g., family responsibilities) matter in the gender gap in entrepreneurship, but also deeper factors that lie "under the skin", something as fundamental as a person's basic personality structure. The results thus illustrate the need for more complex, integrative models that a) consider personality, and its interplay with the other factors that together drive the gender gap in entrepreneurial behaviour and b) inform the further development of promotion programs that stimulate female entrepreneurship more effectively.

Based on the results of research aimed at the comparison of Czech and Polish female traits approach to entrepreneurship of Lituchy and Reavley (2004) show that the Czech women consider the following traits important (in descending order): sense of humor, flexibility and autonomy, further the need for achievement, risk-taking, dominance and proactivity. Polish women have slightly different preferences (in descending order) - the need for achievement, risk-taking, creativity, self-confidence, adaptability, low need to conform, commitment, proactivity and sense of humour. Taking into account opinions of both groups, personality traits such as the need for achievement, risk-taking, proactivity and sense of humour showed to be the most important for entrepreneurship.

The results of Forlani (2013) indicate that women believe less in their abilities to make financially risky, business development type decisions than men, and that these beliefs are unsubstantiated. Furthermore, women who receive negatively valenced information about their prior decisions' outcomes have lower risktaking self-efficacies than either men, or women receiving positively valenced outcome information.

The results of Majumdar and Varadarajan (2013) show that male and female students were equally strong in terms of their propensity to become future entrepreneurs. Female respondents showed higher risk-taking behaviour than males, which was contradictory to past research findings that have typically found females to be more conservative in risk-taking than males. The estimation results showed that the propensity of future entrepreneurship did not depend on gender - it depended on factors like creativity, motivation and awareness.

Compared to males, females (on average) may take a different approach to business (e.g., they may be more cautious in terms of the resources they commit to their ventures and in growing their businesses) but they are likely to be no less effective when performance is measured taking risk into account. (Watson \& Robinson, 2003)

According to Artz (2017) female and male entrepreneurial success are statistically equal after controlling for risk preferences. In comparison, the analysis of Kepler and Shane (2007) shows that male entrepreneurs were significantly less likely than female entrepreneurs to prefer low-risk/low-return businesses. 
Education of an entrepreneur is a subject of many studies (Garcia, 2013; Zhang, Duysters \& Cloodt, 2013; Zhang, Xu \& Lv, 2010). Their results agree on positive influence of higher education on the entrepreneurship (e. g. amount of new start-ups, innovativeness of firms, entrepreneurial orientation etc.)

Age of an entrepreneur as a control variable is often considered in the research of entrepreneurial behaviour. It is considered as a chronological variable, but it is necessary to realize that it is also a psychological element. E. g. Lévesque and Minniti (2006) found that the costs for the opportunity time increased with age. This fact discourages older individuals from choosing the forms of employment involving risk or postponement of satisfaction. According to Sepúlveda and Bonilla (2014) age affects risk quadratically (first positively, but after some point, negatively), and if there is a prior experience of having shut down a business, risk aversion increases, that is, the probability of feeling a fear of failing, which reduces the probability of becoming an entrepreneur.

\section{METHODOLOGY}

The main aim of the article is to analyse an approach to financial risk according to socio-demographic characteristics and the most relevant traits of an entrepreneur. Analysing, testing and evaluating the perception analysis of the most relevant entrepreneur's traits in relation to financial risks can contribute to better understanding and better company management as well as to better decision making when hiring new employees. Results presented in this article are a part of extended research which was carried out at the Tomas Bata University during the academic year 2015/2016 (projects IGA/FaME/2015/022, GA/2016/2). To complete the main aim of the article, the following statistical statements (SS) were formulated:

\section{SS: Entrepreneurs know how to manage financial risks in their companies. \\ 2SS: The importance of financial risks increased during the crisis. \\ 3SS: Entrepreneurs minimise the negative influence of financial risk by creating financial reserves.}

Statistical finding was realised on a sample of 1650 companies. From this number of companies we managed to collect data of 1141 companies. The success rate of the questionnaire completion in a form of a positive feedback was $70 \%$. To carry out the research we used a method of direct asking and online questionnaire completion

(https://docs.google.com/forms/d/1U9coaC5JRL0N2QOOO6Xb8j3mnaZXdSM47Kugt4EDGFO $\angle$ viewform? $\mathrm{usp}=$ send form). The data was provided by 1141 owners of SMEs in 14 regions of the Czech Republic. The questionnaire consisted of 52 questions (60 476 statistical data). To meet the main aim of the article we used selected 10 questions of the questionnaire (10 485 statistical data of 1141 companies). We also used socio-demographic information of the entrepreneurs (gender, risk-taking, optimism). In the first step of data collection we selected companies from the "Albertina" database by a method of random number selection using a mathematical function "randbetween". The range needed to enter the function was set by a number of companies in a given studied region. Individual companies were addressed via email, by telephone, and also in personal meetings.

To solve the formulated SS which should help characterize entrepreneurs in the area of financial risk and its impact on companies, it was possible to state: I completely agree (score $=2)$, I agree (score $=1)$, I have no idea (score $=0$ ), I disagree (score $=-1$ ), and I completely disagree ( score $=-2$ ). The significance of matching qualitative evaluation with their qualitative expressions is not only in the need of the statistical 
assessment of the realized tests, but also in the opportunity to determine relevance of individual qualitative evaluations.

To assess statistical statements in the area of financial risk we used the following statistical tools of descriptive statistics: tables, descriptive characteristics - average, scattering, and score. The score is calculated by adding all the evaluations. Next we applied statistical methods as absolute quantity and simple classification of a statistical marker, classification according to two statistical markers. By comparing mean values from two mutually independent selections we were able to state whether the evaluation of the selected statistical statements is identical or different in reference with the selected demographic characteristics and in reference with the most relevant personality traits of the entrepreneur. We used a double-choice t-test (non- pair). We tested whether the difference of the mean values between the sets is zero (zero hypothesis) in contrast to a non-zero difference between mean values (alternative hypothesis). All the tests were realised on the level of significance 0.05 . Critical values of acceptance or refusal of the zero hypothesis with the use of the number of degrees of leeway are provided in the subject data evaluation in the tables (t-Statistics and $\mathrm{p}$-value $(\mathrm{P}(\mathrm{T}<=\mathrm{t})))$. Prerequisites for realisation of this test such as regular distribution of the data in sets, independence of the sets, even variance between the sets, were a subject of scrutiny before the actual realisation of the t-test. For the verification of the normality assumption we used a graphic analysis of data (a comparison of data's histogram in a set with a curve of normal distribution), but we also tested with Chisquare test of good agreement (goodness-of-fit). For the verification of statistically irrelevant differences in the scattering we used the F-test. All the conditions for realisation of the double-choice t-test (non-pair) were met. Calculations were realised using a sophisticated statistics software SPSS Statistics.

The structure of the sample according to the residency of entrepreneurship in the Czech Republic was as follows (relative count of enterprises from the total number of 1141 enterprises): : Zlín Region (28.3\%), Moravian-Silesian Region (24.2\%), The Olomouc Region (11.7\%), South Moravian Region (10.2\%), Liberec Region and City of Prague with the same proportion (5.1\%), The Pardubice Region (4.8\%), The Pilsen region (2,7 \%), Central Bohemia Region (2.1\%), Hradec Králové Region (2.0 \%), Vysočina Region (1.6\%), South Bohemian Region (1.0\%), The Ústí Region (0.9 \%) and Karlovy Vary Region (0.3\%). Classification of entrepreneurs who represented a company came with a statistical marker of gender: $75 \%$ of men and $25 \%$ of women. The age characteristic of the entrepreneurs was classified into three groups: up to 35 years $(25 \%)$, from 35 to 45 years $(28 \%)$, above 45 years $(47 \%)$. The company's activities on the market were followed as: a company with the number of active entrepreneurial years less than 10 years (62\%), $17 \%$ of companies from 5 to 10 years, and $21 \%$ of companies with activities on the market from 1 to 5 years. The structure of the companies according to their national-economic orientation was represented in the following area of economy: $33 \%$ trade companies, $23 \%$ manufacturing companies, $14 \%$ construction, $6 \%$ transportation, $3 \%$ agriculture and those which did not provide their area orientation.

\section{EMPIRICAL RESULTS AND DISCUSSION}

As a part of the statistical data collection, there was an option for the entrepreneurs to mark or complete the questionnaire with personality traits (maximum of three) which they would consider crucial and the entrepreneur should not start business if missing those traits. The following sections will be focused on evaluation of those three most important personality traits of an entrepreneur, especially those that are necessary for starting a business. These traits were chosen based on the literature review and comprise risktaking, optimism, decisiveness. 


\section{SS: Entrepreneurs know how to manage financial risks in their companies.}

The total number of entrepreneurs who marked risk-taking trait as one of the most important personality trait was 320 , out of which $77.5 \%$ were men and $22.5 \%$ women. Those with unspecified education $67.2 \% ; 32.8 \%$ with college education; $54.3 \%$ of age over $35 \mathrm{yrs}$ and $45.6 \%$ with age over $45 \mathrm{yrs}$. A critical value of t-test when calculating statistical characteristics (gender, education and age) with regard to characteristics (risk-taking, optimism, decisiveness) was calculated to 1.651. Table 1 shows the t-test results with reference to individual traits evaluated in SS1.

Table 1

The results of statistical statement 1 with regard to entrepreneur's personality traits

\begin{tabular}{|c|c|c|c|c|c|c|}
\hline \multicolumn{7}{|c|}{ Trait - risk-taking } \\
\hline \multirow{2}{*}{ Characteristics } & \multicolumn{2}{|c|}{ Gender } & \multicolumn{2}{|c|}{ Education } & \multicolumn{2}{|c|}{ Age } \\
\hline & Men & Women & $\mathrm{OE}$ & $\mathrm{HE}$ & -45 & $45+$ \\
\hline Number & 248 & 72 & 215 & 105 & 174 & 146 \\
\hline Score & -19 & -5 & 0 & -24 & -7 & -17 \\
\hline Mean & -0.077 & -0.069 & 0.000 & -0.228 & -0.040 & -0.116 \\
\hline $\mathrm{t}$-Statistics & \multicolumn{2}{|c|}{-0.061} & \multicolumn{2}{|c|}{2.216} & \multicolumn{2}{|c|}{0.779} \\
\hline $\mathrm{P}(\mathrm{T}<=\mathrm{t})$ & \multicolumn{2}{|c|}{0.476} & \multicolumn{2}{|c|}{0.013} & \multicolumn{2}{|c|}{0.218} \\
\hline \multicolumn{7}{|c|}{ Trait-Decisiveness } \\
\hline \multirow{2}{*}{ Characteristics } & \multicolumn{2}{|c|}{ Gender } & \multicolumn{2}{|c|}{ Education } & \multicolumn{2}{|c|}{ Age } \\
\hline & Men & Women & OE & $\mathrm{HE}$ & -45 & $45+$ \\
\hline Number & 183 & 55 & 143 & 95 & 121 & 117 \\
\hline Score & -2 & -3 & 0 & -5 & 0 & -5 \\
\hline Mean & -0.011 & -0.055 & 0.000 & -0.052 & 0.000 & -0.043 \\
\hline $\mathrm{t}$ - Statistics & \multicolumn{2}{|c|}{0.344} & \multicolumn{2}{|c|}{0.482} & \multicolumn{2}{|c|}{0.399} \\
\hline $\mathrm{P}(\mathrm{T}<=\mathrm{t})$ & \multicolumn{2}{|c|}{0.366} & \multicolumn{2}{|c|}{0.315} & \multicolumn{2}{|c|}{0.345} \\
\hline \multicolumn{7}{|c|}{ Trait-Optimism } \\
\hline \multirow{2}{*}{ Characteristics } & \multicolumn{2}{|c|}{ Gender } & \multicolumn{2}{|c|}{ Education } & \multicolumn{2}{|c|}{ Age } \\
\hline & Men & Women & $\mathrm{OE}$ & $\mathrm{HE}$ & -45 & $45+$ \\
\hline Number & 51 & 22 & 50 & 23 & 42 & 31 \\
\hline Score & -12 & -1 & -6 & -7 & -3 & -10 \\
\hline Mean & -0.235 & -0.045 & -0.120 & -0.304 & -0.071 & -0.323 \\
\hline $\mathrm{t}$ - Statistics & \multicolumn{2}{|c|}{-0.869} & \multicolumn{2}{|c|}{0.854} & \multicolumn{2}{|c|}{1.245} \\
\hline $\mathrm{P}(\mathrm{T}<=\mathrm{t})$ & \multicolumn{2}{|c|}{0.194} & \multicolumn{2}{|c|}{0.198} & \multicolumn{2}{|c|}{0.109} \\
\hline
\end{tabular}

Source: Authors' results. HE indicates higher education, OE indicates other education (secondary school and high school with graduation), -45 indicates entrepreneurs up to 45 years, $45+$ indicates entrepreneurs older than 45 years.

The results of the proportionate evaluation done by the entrepreneurs show a rather negative attitude (disagree) towards the subject statement with no regard to socio-demographic factor or entrepreneur's personality traits. The only exception from this statement is the factor of unspecified education with a risk-taking trait and decisiveness, where the mean value 0.000 can be interpreted as an adequately equal number of entrepreneurs agree and also disagree with this statement. Results presented in Table 1 can be interpreted in a way that there exist statistically relevant differences in evaluation of statistical statement 1 concerning entrepreneurs and their statistical marker of education. Those marked the risk-taking trait as one of the three most important traits of an entrepreneur ( $\mathrm{t}-$ Statistics $=2.216 ; \mathrm{P}(\mathrm{T}<=\mathrm{t})=0.013$ ). 
The rest of the realised tests brought statistically unimportant differences between the mean evaluations of entrepreneurs, thus in those cases we accept zero hypothesis.

\section{SS: The importance of financial risk increased during the crisis.}

The total number of entrepreneurs who marked decisiveness as one of the three most important traits of an entrepreneur was 238. Out of those $77 \%$ men and $23 \%$ women; $60 \%$ entrepreneurs with unspecified education, $40 \%$ entrepreneurs with college education, $51 \%$ in age up to $35 \mathrm{yrs}$ and $49 \%$ in age over 45 yrs. Calculations of t-test with regard to individual traits related to SS 2 are presented in Table 2.

Table 2

The results of statistical statement 2 with regard to entrepreneur's personality traits

\begin{tabular}{|c|c|c|c|c|c|c|}
\hline \multicolumn{7}{|c|}{ Trait - Risk-taking } \\
\hline \multirow{2}{*}{ Characteristics } & \multicolumn{2}{|c|}{ Gender } & \multicolumn{2}{|c|}{ Education } & \multicolumn{2}{|c|}{ Age } \\
\hline & Men & Women & $\mathrm{OE}$ & $\mathrm{HE}$ & -45 & $45+$ \\
\hline Number & 248 & 72 & 215 & 105 & 174 & 146 \\
\hline Score & 175 & 52 & 151 & 76 & 119 & 108 \\
\hline Mean & 0.706 & 0.722 & 0.702 & 0.724 & 0.684 & 0.740 \\
\hline $\mathrm{t}$-Statistics & \multicolumn{2}{|c|}{-0.184} & \multicolumn{2}{|c|}{-0.268} & \multicolumn{2}{|c|}{-0.740} \\
\hline $\mathrm{P}(\mathrm{T}<=\mathrm{t})$ & \multicolumn{2}{|c|}{0.427} & \multicolumn{2}{|c|}{0.394} & \multicolumn{2}{|c|}{0.230} \\
\hline \multicolumn{7}{|c|}{ Trait - Decisiveness } \\
\hline \multirow{2}{*}{ Characteristics } & \multicolumn{2}{|c|}{ Gender } & \multicolumn{2}{|c|}{ Education } & \multicolumn{2}{|c|}{ Age } \\
\hline & Men & Women & $\mathrm{OE}$ & $\mathrm{HE}$ & -45 & $45+$ \\
\hline Number & 183 & 55 & 143 & 95 & 121 & 117 \\
\hline Score & 131 & 25 & 101 & 58 & 67 & 92 \\
\hline Mean & 0.716 & 0.509 & 0.706 & 0.611 & 0.554 & 0.786 \\
\hline $\mathrm{t}$ - Statistics & \multicolumn{2}{|c|}{1.979} & \multicolumn{2}{|c|}{1.059} & \multicolumn{2}{|c|}{-2.657} \\
\hline $\mathrm{P}(\mathrm{T}<=\mathrm{t})$ & \multicolumn{2}{|c|}{0.025} & \multicolumn{2}{|c|}{0.145} & \multicolumn{2}{|c|}{0.004} \\
\hline \multicolumn{7}{|c|}{ Trait - Optimism } \\
\hline \multirow{2}{*}{ Characteristics } & \multicolumn{2}{|c|}{ Gender } & \multicolumn{2}{|c|}{ Education } & \multicolumn{2}{|c|}{ Age } \\
\hline & Men & Women & $\mathrm{OE}$ & $\mathrm{HE}$ & -45 & $45+$ \\
\hline Number & 51 & 22 & 50 & 23 & 42 & 31 \\
\hline Score & 18 & 9 & 13 & 14 & 2 & 25 \\
\hline Mean & 0.353 & 0.409 & 0.260 & 0.609 & 0.048 & 0.806 \\
\hline $\mathrm{t}$-Statistics & \multicolumn{2}{|c|}{-0.246} & \multicolumn{2}{|c|}{-1.771} & \multicolumn{2}{|c|}{-3.950} \\
\hline $\mathrm{P}(\mathrm{T}<=\mathrm{t})$ & \multicolumn{2}{|c|}{0.403} & \multicolumn{2}{|c|}{0.040} & \multicolumn{2}{|c|}{0.001} \\
\hline
\end{tabular}

Source: Authors' results. HE indicates higher education, OE indicates other education (secondary school and high school with graduation), -45 indicates entrepreneurs up to 45 years, $45+$ indicates entrepreneurs older than 45 years.

The results of the proportionate evaluation done by the entrepreneurs show a positive attitude (agree) towards the subject statement with no regard to socio-demographic factor or entrepreneur's personality traits. Results presented in Table 2 can be interpreted in a way that there exist statistically relevant differences in evaluation of statistical statement 2 concerning entrepreneurs of two socio-demographic characteristics. Those marked the decisiveness trait as one of the three most important traits of an entrepreneur (gender: $t$ - 
Statistics $=1.979$; age: t-Statistics $=-2.657$, the same as with the two characteristics, those who marked optimism trait as one of the three most important traits of an entrepreneur (education: t-Statistics $=-1.771$; age: $\mathrm{t}$-Statistics $=-3.950)$.

\section{SS: Entrepreneurs minimise negative influence of financial risk by creating financial reserves.}

The total number of those entrepreneurs who marked optimism as one of the three most important traits of an entrepreneur was 72. Out of those 70\% men and 30\% women; 68\% entrepreneurs with unspecified education, $32 \%$ entrepreneurs with college education, $58 \%$ in age up to $35 \mathrm{yrs}$ and $42 \%$ in age over 45 yrs. Calculations of t-test with regard to individual traits related to SS 3 are presented in Table 3.

Table 3

The results of statistical statement 3 with regard to entrepreneur's personality traits

\begin{tabular}{|c|c|c|c|c|c|c|}
\hline \multicolumn{7}{|c|}{ Trait - risk-taking } \\
\hline \multirow{2}{*}{ Characteristics } & \multicolumn{2}{|c|}{ Gender } & \multicolumn{2}{|c|}{ Education } & \multicolumn{2}{|c|}{ Age } \\
\hline & Men & Women & $\mathrm{OE}$ & $\mathrm{HE}$ & -45 & $45+$ \\
\hline Number & 248 & 72 & 215 & 105 & 174 & 146 \\
\hline Score & 22 & 24 & 34 & 12 & 40 & 6 \\
\hline Mean & 0.089 & 0.333 & 0.158 & 0.114 & 0.230 & 0.041 \\
\hline $\mathrm{t}-$ Statistics & \multicolumn{2}{|c|}{-1.976} & \multicolumn{2}{|c|}{0.396} & \multicolumn{2}{|c|}{1.817} \\
\hline $\mathrm{P}(\mathrm{T}<=\mathrm{t})$ & \multicolumn{2}{|c|}{0.025} & \multicolumn{2}{|c|}{0.346} & \multicolumn{2}{|c|}{0035} \\
\hline \multicolumn{7}{|c|}{ Trait - Decisiveness } \\
\hline \multirow{2}{*}{ Characteristics } & \multicolumn{2}{|c|}{ Gender } & \multicolumn{2}{|c|}{ Education } & \multicolumn{2}{|c|}{ Age } \\
\hline & Men & Women & $\mathrm{OE}$ & $\mathrm{HE}$ & -45 & $45+$ \\
\hline Number & 183 & 55 & 143 & 95 & 121 & 117 \\
\hline Score & 32 & 4 & 25 & 11 & 32 & 4 \\
\hline Mean & 0.175 & 0.073 & 0.175 & 0.116 & 0.264 & 0.034 \\
\hline $\mathrm{t}$ - Statistics & \multicolumn{2}{|c|}{0.701} & \multicolumn{2}{|c|}{0.470} & \multicolumn{2}{|c|}{1.885} \\
\hline $\mathrm{P}(\mathrm{T}<=\mathrm{t})$ & \multicolumn{2}{|c|}{0.242} & \multicolumn{2}{|c|}{0.319} & \multicolumn{2}{|c|}{0.030} \\
\hline \multicolumn{7}{|c|}{ Trait - Optimism } \\
\hline \multirow{2}{*}{ Characteristics } & \multicolumn{2}{|c|}{ Gender } & \multicolumn{2}{|c|}{ Education } & \multicolumn{2}{|c|}{ Age } \\
\hline & Men & Women & $\mathrm{OE}$ & $\mathrm{HE}$ & -45 & $45+$ \\
\hline Number & 51 & 22 & 50 & 23 & 42 & 31 \\
\hline Score & -3 & 6 & 5 & -2 & 13 & -10 \\
\hline Mean & -0.059 & 0.273 & 0.100 & -0.087 & 0.310 & -0.323 \\
\hline $\mathrm{t}$ - Statistics & \multicolumn{2}{|c|}{-1.378} & \multicolumn{2}{|c|}{0.780} & \multicolumn{2}{|c|}{2.960} \\
\hline $\mathrm{P}(\mathrm{T}<=\mathrm{t})$ & \multicolumn{2}{|c|}{0.086} & \multicolumn{2}{|c|}{0.219} & \multicolumn{2}{|c|}{0.002} \\
\hline
\end{tabular}

Source: Authors' results. HE indicates higher education, OE indicates other education (secondary school and high school with graduation), -45 indicates entrepreneurs up to 45 years, $45+$ indicates entrepreneurs older than 45 years.

The results of the proportionate evaluation done by the entrepreneurs show a rather positive attitude (agree) towards the subject statement regarding entrepreneur's traits such as risk-taking and decisiveness. On the contrary, regarding the optimism trait there is a rather negative attitude (disagree) towards this 
statistical statement. The results presented in Table 3 can be interpreted in a way that there exist statistically important differences in evaluation of the statistical statement 3 , regarding the respondents:

- According to the statistical marker of gender and age, those who marked risk-taking trait as one of the three most important traits of an entrepreneur (gender: t-Statistics $=-1.976$; age: $\mathrm{t}$-Statistics $=$ 1.817);

- According to the statistical marker of age, those who marked decisiveness as one of the three most important traits of an entrepreneur (gender: t-Statistics $=-1.885$ );

- According to the statistical marker of age, those who marked optimism trait as one of the three most important traits of an entrepreneur (gender: t-Statistics $=2.960$ );

The remaining tests did not show statistically significant differences and thus we accept zero hypothesis for them.

According to Mishra and Lalumière (2011) previous research has demonstrated that such personality traits as impulsivity, sensation-seeking, and low self-control are correlated with risk-taking. Our findings supported these results and such personality traits are proximate mechanisms through which a baseline behavioural preference for risky outcomes is manifested.

Conscious acceptance of business risk is a prerequisite for business success. Every entrepreneurial decision needs risk tolerance. As the outcome of each investment is unpredictable, related decisions are risky. However, there is no unidirectional relationship between risk tolerance and entrepreneurial decision. (Caliendo et al. 2014)

The relationship between profitability and risk is generally known "The greater the risk, the higher expected rate of return." In our opinion and according to other authors (Lituchy \& Reavley, 2004; Kim \& Vonorts, 2014; Caliendo et al. 2014) successful business is inevitably associated with acceptance of some degree of risk.

Veber et al. (2005) and other authors show that the most important personality traits of the entrepreneurs seem to be honesty and creativity (Hines, 2004), conscientiousness (Zhao \& Seibert, 2006), responsibility (Beugelsdijk \& Noorderhaven, 2005), optimism (Frese \& Gielnik, 2014) and initiative (Bruttel \& Fischbacher, 2013) in addition to the aforementioned risk-taking (see also Lituchy \& Reavley, 2004; Majumdar \& Varadarajan, 2013; Kepler \& Shane, 2007).

Our results showed that analysed entrepreneurs are aware of the importance of financial risk and confirmed opinions of e. g. Artz (2017) about no differences in risk-taking between male and female entrepreneurs because there were found no statistically significant differences in relation to the personality trait "risk-taking" in relation to the gender except in the answers to the statement "Entrepreneurs minimise the negative influence of financial risk through reserves". Female entrepreneurs agreed with this statement statistically significantly more than male entrepreneurs, which can indicate much more careful attitude to the future risk and its consequences. Except this finding we did not confirm results of Obschonka et al. (2014), Forlani (2013), Watson and Robinson (2003) or Majumdar and Varadajan (2013) about different approach to risk-taking between male and female entrepreneurs.

The results in the other two analysed characteristics revealed that the most frequent cause of statistically significant differences was the age of entrepreneurs. The statement "The importance of financial risks during the crisis have increased" was supported by entrepreneurs aged 45 and older more often. It corresponds with the fact that older entrepreneurs have much more experience and can compare the situation before and after the crisis. The third statement was supported by more entrepreneurs aged under 45 . These results 
partially confirm the importance of this factor in entrepreneurial behaviour in relation to risk-taking (for more examples see Sepúlveda \& Bonilla, 2014; Lévesque \& Minniti, 2006).

Education of the entrepreneur appeared to be a reason of statistically significant differences twice. Firstly in personality trait "risk-taking" and secondly in personality trait "optimism". Graduated entrepreneurs realized the importance of financial risk statistically more often than others.

\section{CONCLUSION}

Our results showed that most analysed entrepreneurs didn't agree with the statement "entrepreneurs can properly manage financial risks in their companies". In relation to the analyzed personality trait "risktaking" there were no statistically significant differences between the defined groups according to gender and age but we have revealed statistically significant differences in relation to education of entrepreneurs ( $\mathrm{p}$ value: 0.013$)$. In relation to other personality traits "decisiveness" and "optimism" we have not found any statistically significant differences.

On average, we have found that analysed entrepreneurs agreed with the statement: "The importance of financial risks during the crisis have increased" regardless of the selected socio-demographic characteristics or personality traits. Statistically significant differences were revealed in the answers to this question due to "decisiveness" in relation to gender ( $\mathrm{p}$-value: 0.025$)$ and age ( $\mathrm{p}$-value: 0.004$)$ and due to "optimism" in relation to education (p-value: 0.040) and age (p-value: 0.001).

The entrepreneurs who selected personality traits "risk-taking" and "decisiveness" on average agreed with the statement "Entrepreneurs minimise the negative influence of financial risk through reserves". In comparison with the entrepreneurs who selected "optimism" because they rather didn't agree with this statement. Statistically significant differences were also found in relation to personality trait "risk-taking" due to gender ( $\mathrm{p}$-value: 0.025$)$ and age ( $\mathrm{p}$-value: 0.035); further in relation to "decisiveness" due to age ( $\mathrm{p}$ value: 0.030 ); and lastly in relation to "optimism" due to age (p-value: 0.002 ).

The results of this paper can be usefull especially for regional educational policy in relation to improvement of crucial personality characteristics of entrepeneurs. In practice, it can be realised through various educational courses (in various forms - workshop, seminar, lecturer, brochure) organised by cooperation of regional government, universities aimed at entrepreneurship and other different subjects supporting start-ups and growth of entrepreneurial environment of SMEs.

Although it is clear that there are certain limits to our research (e. g. uneven representation of respondents by region or gender), we believe that our article presents interesting findings and new incentives for further research.

Our future research is going to concentrate on the research of managing financial risk in the SME sector in the Czech Republic in more depth and also on the influence of the most important sociodemographic characteristics.

\section{ACKNOWLEDGEMENT}

The authors would like to thank the Internal Grant Agency of FaME for providing financial support to carry out this research. Funding was extended through: TBU No. IGA/FaME/2015/022 - The Influence of Socio-demographic Characteristics on the Entrepreneurial Orientation of SMEs entrepreneurs and through GA AA GA/2016/2 - Important Determinants of Entrepreneurial Environment's Quality of SMEs in the Czech Republic. 


\section{REFERENCES}

Artz, B. (2017). Gender and entrepreneurial success: evidence from survey data. Applied Economics Letters, 24(3), 163166. doi: http://dx.doi.org/10.1080/13504851.2016.1173173.

Belluchi, A., Borisov, A., \& Zazzaro, A. (2010). Does gender matter in bank-firm relationships? Evidence from small business lending. Journal of Banking and Finance, 34(12), 2968-2984. doi: http://dx.doi.org/10.1016/j.jbankfin.2010.07.008.

Bruttel, L., \& Fischbacher, V. (2013). Taking the initiative. What characterizes leaders? European Economic Review, 64, 147-168. doi: http://dx.doi.org/10.1016/j.euroecorev.2013.08.008.

Caliendo, M., Fossen, F., \& Kritikos, A. S. (2014). Personality characteristics and the decisions to become and stay self-employed. Small Bus Econ, 42, 787-814. doi: http:/ /dx.doi.org/10.1007/s11187-013-9514-8.

Dai, L., Maksimov, V., Gilbert, B. A., \& Fernhaber, S. A. (2014). Entrepreneurial orientation and international scope: The differential roles of innovativeness, proactiveness, and risk-taking. Journal of Business Venturing, 29(4), 511524. doi: http://dx.doi.org/10.1016/j.busvent.2012.07.004.

Feakins, M. (2004). Commercial Bank Lending to SMEs in Poland. Small Business Economics, 23, 51-70. doi: http://dx.doi.org/10.1023/B:SBEJ.0000026025.04815.bc.

Fetisovova, E. et al. (2012). Aktuálne problémy financii malých a stredných podnikov. Ekonóm, Bratislava.

Forlani, D. (2013). How Task Structure and Outcome Comparisons Influence Women's and Men's Risk-Taking Self Efficacies: A Multi-Study Exploration. Psychology and Marketing, 30(12), 1088-1107. doi: http://dx.doi.org/10.1002/mar.20669.

Frese, M., \& Gielnik, M. M. (2014). The Psychology of Entrepreneurship. Annual Review of Organizational Psychology and Organizational Behavior, 1, 413-438. doi: http://dx.doi.org/10.1146/annurev-orgpsych-031413-091326.

García, A. B. (2013). Analyzing the determinants of entrepreneurship in European cities. Small Bus Econ, 42, 77-98. doi: http://dx.doi.org/10.1007/s11187-012-9462-8.

Hall, A. (2012). Top Characteristics of Successful Entrepreneurs: Larry Levy, Kellogg School of Management, Weighs In. Forbes. Retrieved from: http://www.forbes.com/sites/alanhall/2012/10/24/top-characteristics-ofsuccessful-entrepreneurs-larry-levy-kellog-school-of-management-weighs-in/\#2ecb32291ac7.

Hines, J. L. (2004). Characteristics of an entrepreneur. Surgical Neurology, 61(4), 407-408. doi: http://dx.doi.org/10.1016/j.surneu.2003.05.004.

Kepler, E., \& Shane, S. (2007). Are Male and Female Entrepreneurs Really That Different? Small Business Research Summary, 309.

Kim, Y., \& Vonorts, N. S. (2014). Managing risk in the formative years: evidence from young enterprises in Europe. Technovation, 34, 454-465. doi: http://dx.doi.org/10.1016/i.technovation.2014.05.004.

Kundin, A., \& Erecgovac, R. (2011). Credit Rationing in Financial Distress: Croatia's SMEs Finance Approach. International Journal of Law and Management, 53(1), 62-84. doi: https://doi.org/10.1108/17542431111111890.

Lévesque, M., \& Minniti, M. (2006). The effect of ageing on entrepreneurial behavior. Journal of Business Venturing, 21(2), 177-194.

Lituchy, T. R., \& Reavley, M. A. (2004). Women Entrepreneurs: A Comparison of International Small Business Owners in Poland and the Czech Republic. Journal of International Entrepreneurship, 2(1), 61-87. doi: http://dx.doi.org/10.1023/B:JIEN.0000026906.28190.df.

Majumdar, S., \& Varadarajan, D. (2013). Students'attitude towards entrepreneurship: Does gender matter in the UAE? Foresight, 15(4), 278-293.

Mishra, S., \& Lalumière, M. L. (2011). Individual differences in risk-propensity: Associations between personality and behavioral measures of risk. Personality and Individual Differences, 50, 869-873. doi: http://dx.doi.org/10.1016/i.paid.2010.11.037.

Obschonka, M., Schmitt-Rodermund, E., \& Terracciano, A. (2014). Personality and the Gender Gap in SelfEmployment: A Multi-Nation Study. PLoS ONE, 9(8). doi: http://dx.doi.org/10.1371/journal.pone.0103805.

Omerzel, G. D., \& Kušce, I. (2013). The influence of personal and environmental factors on entrepreneurs' performance. Kybernetes, 42(6), 906-927.

Pofeldt, E. (2014). Gallup: The 10 Qualities of Highly Successful Entrepeneurs. Forbes. Retrieved from: http://www.forbes.com/sites/elainepofeldt/2014/05/31/gallup-the-10-qualities-of-highly-successfulentrepreneurs/\#5f019dd44f8a. 
Rad, A., Yazdanfar, D., \& Öhman, P. (2014). Female and male risk aversion. International Journal of Gender and Entrepreneurship, 6(2), 121-141. doi: http://dx.doi.org/10.1108/IJGE-02-2013-0012.

Rampton, J. (2014). 5 Personality Traits of an Entrepreneur. Forbes. Retrieved from: http://www.forbes.com/sites/johnrampton/2014/04/14/5-personality-traits-of-anentrepreneur/\#261cf39622f6.

Sepúlveda, J. P., \& Bonilla, C. A. (2014). The factors affecting the risk attitude in entrepreneurship: evidence from Latin America. Applied Economics Letters, $21(8), \quad 573-581 . \quad$ doi: http://dx.doi.org/10.1080/13504851.2013.875104.

Shuying, Z., \& Mei, Z. (2014). Theory of SMEs financial risk prevention and control. International Conference on Education, Management and Computing Technology, 514-517. doi: http://dx.doi.org/10.2991/icemct-14.2014.126.

Smejkal, V., \& Rais, K. (2006). Řizeni rizik ve firmách a jiných organizacích. Second edition . Grada, Praha.

Ugalde-Binda, N., Balbastre-Benavent, F., Canet-Giner, M. T., \& Escribá-Carda, N. (2014). The role of intellectual capital and entrepreneurial characteristics as innovation drivers. Innovar, 24(53), 41-60. doi: http://dx.doi.org/10.15446/innovar.v24n53.43793.

Veber, J., Srpová, J. a kolektiv (2005). Podnikáni malé a strédni firmy. 1. vyd. Praha: Grada. ISBN 80-247-1069-2.

Vesecký, Z. (2014). Úspěsný podnikatel musí být už od détství lebký antisociál. [cit. 14. 4. 2016]. Retrieved from http://www.podnikatel.cz/clanky/uspesny-podnikatel-musi-byt-uz-od-detstvi-lehky-antisocial/.

Watson, J., \& Robinson, S. (2003). Adjusting for risk in comparing the performance of male- and female-controlled SMEs. Journal of Business Venturing, 18(6), 773-788. doi: http://dx.doi.org/10.1016/S0883-9026(02)00128-3.

Zhang, J., Xu, X., \& Lv, R. (2010). Empirical research on Founder's Human Capital and Venture Growth Performance in China. Ifera at China 2010 Family Business Forum: Opportunities and challenges of family business, 219-224.

Zhang, Y., Duisters, G., \& Cloodt, M. (2013). The role of entrepreneurship education as a predictor of university students'enrepreneurial intention. Int Entrep ManagJ, 10, 623-641. doi: http://dx.doi.org/10.1007/s11365-0120246-z.

Zhao, H., \& Seibert, S. E. (2006). The Big Five Personality Dimensions and Entrepreneurial Status: A Meta-Analytical Review. Journal of Applied Psychology, 91(2), 259-271. doi: http://dx.doi.org/10.1037/0021-9010.91.2.259. 